\title{
PENGARUH KEBIJAKAN DIVIDEN, KEBIJAKAN HUTANG DAN \\ PROFITABILITAS TERHADAP NILAI PERUSAHAAN PADA PERUSAHAAN MANUFAKTUR YANG TERDAFTAR DI BURSA EFEK INDONESIA
}

\author{
Derita Rosalina Sihotang \\ Joana L. Saragih
}

\begin{abstract}
Abstrak
Penelitian ini bertujuan untuk mengetahui dan menganalisis pengaruh kebijakan dividen, kebijakan hutang dan profitabilitas terhadap nilai perusahaan pada perusahaan manufaktur di Bursa Efek Indonesia. Teknik pengambilan sampel yang digunakan adalah purposive sampling dengan jumlah sampel sebanyak 27 perusahaan. Data diperoleh dari Bursa Efek Indonesia tahun 2009 sampai dengan 2013. Teknik analisis data yang digunakan adalah regresi linier berganda dan pengujian hipotesis menggunakan uji $\mathrm{t}$ dan uji $\mathrm{F}$ dengan tingkat signifikansi sebesar 5\%. Hasil uji secara parsial (uji t) menunjukkan bahwa kebijakan dividen mempunyai pengaruh posititif dan signifikan terhadap nilai perusahaan, kebijakan hutang mempunyai pengaruh negatif dan tidak signifikan terhadap nilai perusahaan dan profitabilitas mempunyai pengaruh positif dan signifikan terhadap nilai perusahaan. Hasil uji secara simultan (uji F) menunjukkan bahwa variabel kebijakan dividen, kebijakan hutang dan profitabilitas mempunyai pengaruh signifikan terhadap nilai perusahaan. Nilai perusahaan dapat dijelaskan oleh kebijakan dividen, kebijakan hutang dan profitabilitas sebesar 35,3\%

Kata Kunci : $\quad$ Nilai Perusahaan, Kebijakan Dividen, Kebijakan Hutang dan Profitabilitas
\end{abstract}

\section{A. PENDAHULUAN}

\section{Latar Belakang}

Dalam pendirian perusahaan, tujuan perusahaan adalah memaksimalkan nilai pemegang saham. Nilai pemegang saham akan meningkat apabila nilai perusahaan meningkat yang ditandai dengan tingkat pengembalian investasi yang tinggi pada pemegang saham. Menurut Taswan dan Soliha dalam Jusriani (2013), nilai perusahaan yang tinggi menjadi keinginan pemilik perusahaan, sebab dengan nilai perusahaan yang tinggi menunjukkan kemakmuran pemegang saham juga tinggi. Nilai perusahaan yang tinggi akan membuat pasar percaya tidak hanya pada kinerja perusahaan saat ini namun juga pada prospek perusahaan.

Menurut Brigham dan Houston (2006) kebijakan dividen merupakan keputusan apakah laba yang diperoleh perusahaan pada akhir tahun akan dibagikan kepada pemegang saham dalam bentuk dividen atau 
ditahan untuk menambah modal guna pembiayaan investasi dimasa yang akan datang. Kebijakan dividen di ukur dengan Dividend Payout Ratio (DPR). Variabel ini dinyatakan dalam rasio dividen per lembar saham dengan laba per lembar saham akhir tahun. Dividend Payout Ratio (DPR) merupakan suatu proksi mengukur kebijakan perusahaan untuk membayarkan dividen (payout) terhadap nilai perusahaan.

Menurut Brigham dan Houston (2006) kebijakan hutang, yaitu kebijakan yang dilakukan oleh perusahaan untuk menjalankan operasionalnya dengan menggunakan hutang keuangan atau financial leverage. Hutang merupakan sumber pendanaan eksternal perusahaan untuk menjalankan kegiatan operasionalnya. Kebijakan hutang itu sendiri diukur dengan Debt to Equity Ratio (DER). Kasmir (2008) Debt to Equity Ratio (DER) merupakan rasio yang digunakan untuk mengetahi perbandingan antara total utang dengn modal sendiri. Rasio ini berguna untuk mengetahui seberapa besar aktiva perusahaan dibiayai dari utang.

Menurut Sartono (2001) profitabilitas adalah kemampuan perusahaan memperoleh laba dalam hubungannya dengan penjualan, total aktiva maupun modal sendiri. Rasio profitabilitas menunjukan efektifitas perusahaan dalam menghasilkan tingkat keuntungan dengan serangkaian pengelolaan aset yang dimiliki perusahaan sehingga profitabilitas mampu untuk mempengaruhi persepi investor terhadap perusahaan mengenai prospek perusahaan dimasa yang akan datang karena dengan tingkat profitabilitas yang tinggi maka semakin tinggi juga minat investor terhadap harga saham perusahaan. Profitabilitas dalam penelitian ini diukur dengan ROE. ROE merupakan perbandingan antara laba bersih setelah pajak dengan ekuitas yang akan diinvestasikan pemegang saham pada perusahaan. Rasio ini menunjukkan kemampuan perusahaan dalam modal ekuitas untuk menghasilkan laba.

Nilai perusahaan merupakan persepsi investor terhadap perusahaan dimana hal ini sering dikaitkan dengan harga saham perusahaan tersebut. Sujoko dan Soebiantoro dalam Andianto Abdillah (2012) menjelaskan bahwa nilai perusahaan merupakan persepsi investor terhadap tingkat keberhasilan perusahaan yang sering dikaitkan dengan harga saham. Sedangkan menurut Husnan (2006), nilai perusahaan merupakan harga yang bersedia dibayar oleh calon pembeli apabila perusahaan tersebut dijual. Dalam penelitian ini, nilai perusahaan diukur dengan Price to Book Value (PBV), yang merupakan perbandingan harga pasar dari suatu saham dengan nilai bukunya. Adapun yang dimaksud dengan nilai buku adalah perbandingan antara modal dengan jumlah saham yang beredar. 
Penelitian mengenai hubungan kebijakan dividen dengan nilai perusahaan menunjukkan hasil yang berbeda diantara peneliti. Bambang (2009) menemukan bahwa kebijakan dividen mempunyai pengaruh positif terhadap nilai perusahaan. Penelitian ini bertentangan dengan pandangan yang dikemukakan oleh Umi Mardiyati, Gatot Nazir dan Ria Putri (2012) yang menyatakan bahwa kebijakan dividen secara parsial memiliki pengaruh yang tidak signifikan terhadap nilai perusahaan. Putri Prihatin Ningsih dan Iin Indarti (2010) menyatakan bahwa kebijakan dividen tidak berpengaruh positif dan signifikan terhadap nilai perusahaan. Dividen yang lebih rendah ternyata dapat meningkatkan nilai perusahaan begitupun sebaliknya dividen yang lebih tinggi dapat menurunkan nilai perusahaan. Sedangkan, menurut Kartini dalam Jusriani (2012) mengenai reaksi pemegang saham terhadap pengumuman perubahan pembayaran dividen di BEI menunjukkan bahwa pengumuman kenaikan dividen berpengaruh negatif terhadap harga saham secara signifikan. Artinya, kenaikan dividen menyebabkan penurunan harga saham, sedangkan pengumuman penurunan dividen juga mengakibatkan penurunan harga saham Andinata dalam Jusriani (2012).

Penelitian mengenai hubungan kebijakan utang dengan nilai perusahaan juga menunjukkan hasil yang berbeda. Bambang (2009) menemukan bahwa kebijakan utang berpengaruh negatif terhadap nilai perusahaan. Temuan ini bertentangan dengan temuan Umi Mardiyati, Gatot Nazir dan Ria Putri (2012) bahwa kebijakan utang berpengaruh positif tetapi tidak signifikan terhadap nilai perusahaan. Temuan ini menunjukkan bahwa peningkatan utang akan meningkatkan nilai perusahaan.

Hasil penelitian Umi Mardiyati, Gatot Nazir Ahmad dan Ria Putri (2012) menyatakan bahwa profitabilitas memiliki pengaruh yang positif signifikan terhadap nilai perusahaan. Hasil penelitian ini konsisten dengan hasil penelitian yang dilakukan oleh Taswan dan Soliha dalam Jusriani (2012) yang menyatakan bahwa profitabilitas berpengaruh positif dan signifikan terhadap nilai perusahaan. Profitabilitas yang tinggi memberikan indikasi prospek perusahaan yang baik sehingga dapat memicu investor untuk ikut meningkatkan permintaan saham yang dapat meningkatkan nilai perusahaan. Tapi temuan ini bertentangan dengan temuan Dedi Januardy (2013) yang menyatakan secara parsial profitabilitas tidak berpengaruh terhadap nilai perusahaan.

Penelitian ini merupakan replikasi dari penelitian sebelumnya, yaitu penelitian yang dilakukan oleh Bambang (2009), adapun perbedaan 
penelitian saat ini dengan penelitian sebelumnya yaitu: pada penelitian Bambang (2009), menggunakan pengaruh kebijakan hutang, kebijakan investasi dan kebijakan dividen terhadap nilai perusahaan, sedangkan pada penelitian ini ada perubahan variabel yaitu kebijakan dividen, kebijakan hutang dan profitabilitas terhadap nilai perusahaan. Periode penelitian Bambang (2009) adalah pada periode 2003-2007 sedangkan penelitian ini menggunakan periode 2009-2013 dengan alasan kondisi perekonomian pada periode 2003-2007 berbeda dengan periode 2009-2013. Selain itu, penelitian ini dilakukan pada tahun 2015 sedangkan penelitian sebelumnya dilakukan pada tahun 2009. Berdasarkan latar belakang maka rumusan masalah dalam penelitian ini apakah kebijakan dividen, kebijakan hutang dan profitabilitas berpengaruh signifikan baik secara parsial maupun simultan terhadap nilai perusahaan pada perusahaan manufaktur yang terdaftar di Bursa Efek Indonesia ? dan tujuan penelitian ini adalah untuk menganalisis pengaruh dividen, kebijakan hutang dan profitabilitas terhadap nilai perusahaan pada perusahaan manufaktur di Bursa Efek Indonesia.

\section{B. Landasan Teori}

\section{Nilai Perusahaan}

Atmaja (2003) menyatakan bahwa teori-teori keuangan di bidang keuangan perusahaan memiliki satu fokus yaitu: bagaimana memaksimumkan kemakmuran pemegang saham atau pemilk perusahaan? Tujuan normatif ini dapat diwujudkan dengan memaksimumkan nilai perusahaan dengan asumsi bahwa pemegang saham akan makmur jika kantongnya bertambah tebal. Memaksimumkan nilai pasar perusahaan sama dengan memaksimumkan harga pasar saham. Nilai perusahaan ( $\mathrm{V}=$ value) adalah hutang $(\mathrm{D}=$ debt $)$ ditambah modal sendiri $(\mathrm{E}=$ equity). Jika utang diasumsikan tetap, nilai perusahaan naik maka modal sendiri akan naik. Naiknya modal sendiri akan menaikkan harga lembar per saham perusahaan. Jika harga per lembar saham naik, pemegang saham akan senang karena bertambah makmur.

Nilai perusahaan adalah harga sebuah saham yang telah beredar di pasar saham yang harus dibayar oleh investor untuk dapat memiliki sebuah perusahaan go public memungkinkan masyarakat maupun manajemen mengetahui nilai perusahaan, nilai perusahaan tercermin pada kekuatan tawar-menawar saham, apabila perusahaan diperkirakan sebagai perusahaan yang mempunyai prospek yang bagus dimasa yang akan 
datang, nilai saham akan menjadi semakin tinggi. Sebaliknya, apabila perusahaan dinilai kurang mempunyai prospek maka harga saham menjadi lemah. Semakin tinggi harga saham semakin tinggi nilai perusahaan. Taswan dan Soliha dalam Jusriani (2013) menyatakan nilai perusahaan yang tinggi menjadi keinginan para pemilik perusahaan, sebab dengan nilai yang tinggi menunjukkan kemakmuran pemegang saham juga tinggi.

Menurut Suad Husnan (2006) nilai perusahaan merupakan harga yang bersedia dibayar oleh calon pembeli apabila perusahaan tersebut dijual. Dalam melakukan aktivitas dan pengambilan keputusan, perusahaan selalu berpatokan pada tujuan utamanya. Menurut Bringham dan Houston (2006) memaksimalkan kekayaan pemilik atau pemegang saham identik dengan memaksimalisasi nilai perusahaan. Apabila nilai perusahaan yang baik, yaitu mempunyai kinerja dan prospek yang bagus, maka investor pasti bersedia membayar lebih untuk membeli sahamnya. Jadi secara sederhana nilai perusahaan dapat diartikan sebagian harga yang bersedia dibayar oleh investor untuk memiliki suatu perusahaan

Nilai perusahaan dalam penelitian ini diukur dengan price to book value (PBV). Price to book value (PBV) adalah suatu rasio yang sering digunakan untuk menentukan nilai perusahaan dan mengambil keputusan investasi dengan cara membandingkan harga pasar per saham dengan nilai buku perusahaan. Harga pasar per saham merupakan harga yang disepakati oleh penjual dan pembeli pada saat terjadinya transaksi per lembar saham. Sedangkan untuk nilai buku per saham merupakan harga pada saat aktiva tersebut diperoleh (nilai historis) per lembar saham, Andinata (2010). PBV $=\frac{\text { Harga Pasar per Saham }}{\text { Nilai Buku per Saham }}$

Salah satu bentuk investasi yang diperjualbelikan di dalam pasar modal adalah saham. Brigham dan Houston (2006) mendefinisikan saham, sebagai surat berharga sebagai bukti penyertaan atau pemilikan individu maupun intitusi dalam suatu perusahaan. Dengan menyertakan modal tersebut maka pihak tersebut memiliki klaim atas pendapatan perusahaan, klaim atas perusahaan, dan berhak hadir dalam Rapat Umum Pemegang Saham (RUPS). Tujuan utama para investor menanamkan dananya ke sebuah perusahaaan yaitu untuk memperoleh pendapatan atau tingkat pengembalian investasi (return).

\section{Kebijakan Deviden}

Menurut Sartono (2001) kebijakan dividen adalah keputusan apakah laba yang diperoleh perusahaan akan dibagikan kepada pemegang saham 
sebagai dividen atau akan ditahan dalam bentuk laba ditahan guna pembiayaan investasi di masa datang. Menurut Brigham dan Houston (2006) kebijakan dividen yang optimal akan menyeimbangkan dividen saat ini dan pertumbuhan dimasa depan sehingga dapat memaksimalkan harga saham perusahaan. Menurut Syahyunan (2013) kebijakan dividen adalah keputusan apakah laba yang diperoleh perusahaan pada akhir tahun akan dibagi kepada pemegang saham dalam bentuk dividen atau akan ditahan untuk menambah modal guna pembiayaan investasi dimasa yang akan datang. Apabila perusahaan memutuskan akan membagi laba perusahaan sebagai dividen, maka akan mengurangi kesempatan perusahaan dalam mendapatkan modal intern. Semakin tinggi dividen yang dibagikan kepada pemegang saham akan mengurangi kesempatan perusahaan dalam mendapatkan sumber dan intern dalam rangka mengadakan reinvestasi, sehingga dalam jangka panjang akan mengurangi nilai perusahaan.

Dalam penelitian ini kebijakan deviden diukur dengan deviden payout ratio. Menurut Sundjaja dan Barlian dalam Karjono dan Matondang (2010), dividend payout ratio adalah persentase dari setiap rupiah yang dihasilkan dibagikan kepada pemilik dalam bentuk tunai dan dihitung dengan membagikan dividen kas per saham dengan laba per saham. Rasio pembayaran dividen ditentukan perusahaan untuk membayar dividen kepada para pemegang saham yang dilakukan setiap tahun. Kebijakan dividen dalam penelitian ini diukur dengan dividend payout ratio (DPR) karena dividend payout ratio (DPR) mengukur bagian laba yang diperoleh untuk per lembar saham umum yang akan dibayarkan dalam bentuk dividen. Rasio ini menunjukkan persentase laba perusahaan yang dibayarkan pada pemegang saham yang berupa dividen kas.

$$
\mathrm{DPR}=\frac{\text { Dividend Per Share }}{\text { Earning Per Share }}
$$

\section{Kebijakan Hutang}

Munawir (2004) hutang adalah semua kewajiban keuangan perusahaan atau modal kepada pihak lain yang belum terpenuhi, dimana hutang ini merupakan sumber dana atau modal perusahaan yang berasal dari kreditor. Hutang merupakan salah satu sumber pembiayaan eksternal yang digunakan oleh perusahaan untuk membiayai kebutuhan dananya. Dalam pengambilan keputusan akan penggunaan utang ini harus mempertimbangkan besarnya biaya tetap yang muncul dari hutang berupa 
bunga yang akan menyebabkan semakin meningkatnya leverage keuangan dan semakin tidak pastinya tingkat pengembalian bagi para pemegang saham. Ketika sebuah perusahaan berekspansi, perusahaan akan membutuhkan modal, dan modal tersebut dapat berasal dari utang maupun ekuitas.

Brigham dan Houston (2010) menyatakan financial Leverage (pengungkit keuangan) adalah sampai sejauh apa perusahaan menggunakan pendanaan melalui utang. Kebijakan hutang perusahaan dapat dilihat dari rasio leverage perusahaan. Leverage adalah rasio yang membandingkan antara dana yang berasal dari pemilik dengan dana yang berasal dari kreditur. Dalam penelitian ini kebijakan hutang diukur dengan debt to equity ratio (DER) karena debt to equity ratio (DER) ini digunakan untuk menilai utang dengan ekuitas dan mencerminkan kemampuan perusahaan dalam memenuhi semua kewajibannya dengan modal dan ekuitas yang ada. DER $=\frac{\text { Total Debt }}{\text { Equity }}$

\section{Profitabilitas}

Sartono (2001) menjelaskan bahwa, Profitabilitas adalah kemampuan perusahaan memperoleh laba dalam hubungannya dengan penjualan, total aktiva maupun modal sendiri. Dengan memperoleh laba yang maksimal perusahaan dapat berbuat banyak bagi kesejahteraan pemilik, karyawan serta meningkatkan mutu produk dan melakukan investasi baru. Dalam praktiknya manajemen perusahaan dituntut harus mampu untuk memenuhi target yang telah ditetapkan. Artinya besarnya keuntungan haruslah dicapai sesuai dengan yang diharapkan dan bukan berarti asal untung. Brigham dan Houston (2010) mengatakan rasio profitabilitas mencerminkan hasil ahir dari seluruh kebijakan keuangan dan keputusan operasional. Menurut Kasmir (2008) rasio profitabilitas merupakan rasio untuk menilai kemampuan perusahaan dalam mencari keuntungan.

Seperti terlihat diatas ada beberapa cara untuk mengukur tingkat profitabilitas perusahaan. Namun, peneliti membatasi hanya menggunakan satu cara yakni dengan memakai rasio Return on Equity (ROE) untuk mengukur profitabilitas perusahaan. Hal ini dapat disimpulkan bahwa rasio yang paling banyak diminati oleh para pemegang saham adalah rasio Return on Equity (ROE) karna rasio ini digunakan untuk mengukur kinerja perusahaan dalam mengelola modal yang tersedia untuk menghasilkan laba 
setelah pajak, semakin tinggi rasio ini semakin baik. Artinya posisi pemilik perusahaan semakin kuat.

Menurut Dedi Januardy (2013) ROE merupakan perbandingan antara laba bersih setelah pajak dengan equitas yang akan diinvestasikan pemegang saham pada perusahaan. Rasio ini menunjukkan kemampuan perusahaan dalam modal ekuitas untuk menghasilkan laba. ROE merupakan tingkat pengembalian ekuitas pemilik perusahaan. Ekuitas pemilik adalah jumlah aktiva bersih perusahaan. Rasio ini juga memperlihatkan sejauh mana perusahaan menghasilkan laba yang dapat diperoleh oleh pemegang saham. $R O E=\frac{\text { Earning After } \text { Tax }}{\text { Total Equity }}$

\section{Pengaruh Kebijakan Dividen terhadap Nilai Perusahaan}

Dividen adalah laba bersih yang diperoleh perusahaan, oleh karena itu dividen akan dibagikan apabila perusahaan memperoleh keuntungan. Menurut Modigliani dan Miller (MM) dalam Atmaja (2003), nilai suatu perusahaan tidak ditentukan oleh besar kecilnya dividend payout ratio (DPR), tetapi ditentukan oleh laba bersih setelah pajak (EBIT) dan kelas resiko perusahaan. Beberapa ahli menyoroti asumsi tidak adanya pajak. Jika ada pajak maka penghasilan investor dari dividen dan capital gain akan dikenai pajak. Seandainya pajak untuk dividen dan capital gain adalah sama, investor cenderung lebih suka menerima capital gain daripada dividen, karena pajak pada capital gain baru dibayar saat saham dijual dan keuntungan diakui. Litzenberger dan Ramaswamy menyatakan bahwa karena adanya pajak terhadap keuntungan dividen dan capital gain, para investor lebih menyukai capital gain karena dapat menunda pajak. Pandangan ini mengemukakan bahwa semakin tinggi dividend payout ratio suatu perusahaan maka nilai perusahaan semakin rendah. Hal ini didasari pada pemikiran bahwa pajak yang dikenakan terhadap capital gain lebih rendah daripada pajak dividen. Teori ini tidak sesuai dengan penelitian yang dilakukan oleh Bambang (2009) yang menyatakan kebijakan dividen berpengaruh positif terhadap nilai perusahaan.

\section{Pengaruh Kebijakan Hutang Terhadap Nilai Perusahaan}

Modigliani dan Miller dalam Atmaja (2003) berpendapat bahwa semakin besar penggunaan hutang akan semakin besar pula risiko dan berarti biaya modal sendiri bertambah. Dengan demikian penggunaan hutang tidak akan meningkatkan nilai perusahaan karena keuntungan dari biaya hutang yang lebih murah ditutup dengan naiknya biaya modal 
sendiri. Pendapat ini kemudian diintrodusir sendiri oleh Modigliani dan Miller pada tahun 1963, yaitu dengan adanya pajak penghasilan perusahaan maka penggunaan hutang akan meningkatkan nilai perusahaan karena biaya bunga hutang adalah biaya yang mengurangi pembayaran pajak. Semakin besar hutang, semakin tinggi nilai perusahaan. Namun demikian peningkatan hutang juga akan menimbulkan peningkatan risiko kebangkrutan bila tidak diimbangi dengan penggunaan hutang yang hatihati. Teori ini juga diperkuat oleh penelitian yang dilakukan Umi Mardiyati, Gatot Nazir dan Ria Putri (2012) yang menyatakan bahwa kebijakan utang berpengaruh positif terhadap nilai perusahaan.

\section{Pengaruh Profitabilitas Terhadap Nilai Perusahaan}

Menurut Sartono (2001) Profitabilitas adalah kemampuan perusahaan memperoleh laba dalam hubungannya dengan penjualan, total aktiva maupun modal sendiri. Makin tinggi laba, makin tinggi return yang diperoleh oleh investor. Tinggi rendahnya tingkat return yang mungkin diterima oleh investor biasanya mempengaruhi penilaian investor. Makin tinggi penilaian investor akan suatu saham, maka harga saham tersebut akan makin tinggi. Harga saham yang makin tinggi akan meningkatkan nilai perusahaan. Hal ini diperkuat oleh penelitian yang dilakukan oleh Taswan dan Soliha dalam Jusriani (2012) yang menyatakan bahwa profitabilitas mempunyai pengaruh positif dan signifikan terhadap nilai perusahaan.

\section{Kerangka Berpikir}

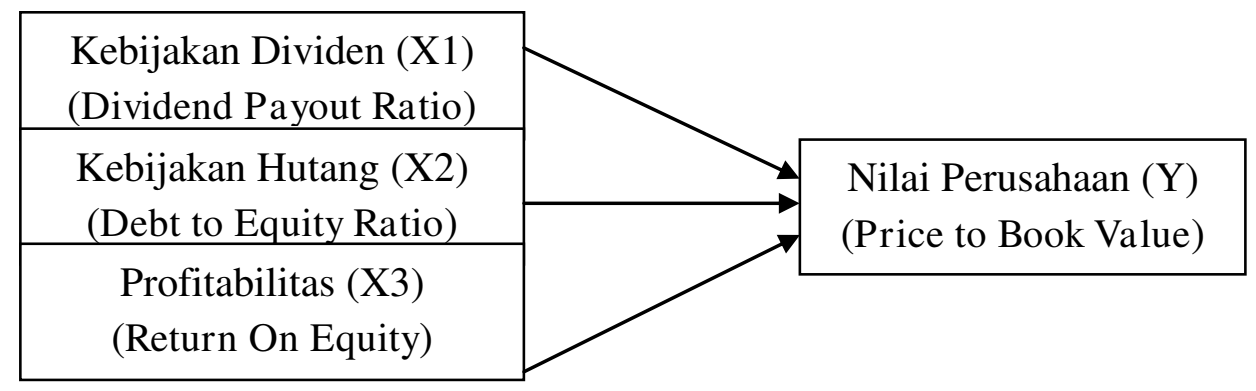

9. Hipotesis

Berdasarkan permasalahan diatas, maka hipotesis dalam penelitian ini adalah sebagai berikut: Kebijakan dividen, kebijakan hutang, dan profitabilitas mempunyai pengaruh yang signifikan secara parsial maupun 
simultan terhadap nilai perusahaan pada perusahaan manufaktur di Bursa Efek Indonesia.

\section{Metode Penelitian}

Data yang digunakan dalam penelitian ini adalah data sekunder dengan teknik dokumentasi yang diperoleh melalui laporan keuangan yang dipublikasikan di Bursa Efek Indonesia (BEI) tahun 2009-2013. Adapun variabel yang diteliti adalah kebijakan dividen, kebijakan hutang, profitabilitas dan nilai perusahaan. Penelitian ini dilakukan melalui situs www.idx.co.id .

\section{Populasi dan Sampel}

Populasi dalam penelitian ini adalah perusahaan manufaktur yang terdaftar di Bursa Efek Indonesia pada tahun 2009-2013 sebanyak 134 perusahaan. Metode penentuan sampel yang digunakan adalah purposive sampling, yaitu penentuan sampel harus memiliki kriteria dan melalui tahapan sebagai berikut:

a. Perusahaan manufaktur yang terdaftar di Bursa Efek Indonesia (BEI) sejak tanggal 01 januari 2009 sampai dengan 31 Desember 2013.

b. Perusahaan yang mempublikasikan laporan keuangan perusahaan manufaktur yang telah diaudit yang memiliki ahir periode fiskal per 31 Desember selama periode 2009 sampai dengan periode 2013.

c. Perusahaan manufaktur menyajikan laporan keuangan dalam mata uang rupiah.

d. Perusahaan manufaktur membagikan dividen setiap tahun selama periode 2009 sampai dengan periode 2013.

Berdasarkan kriteria di atas maka sampel perusahaan manufaktur dalam penelitian ini adalah sebanyak 27 perusahaan.

\section{Operasionalisasi Variabel}

\section{a. Variabel Dependen (Y)}

Variabel dependen dalam penelitian ini adalah nilai perusahaan. Nilai perusahaan dalam penelitian ini diukur dengan Price to book value (PBV). Price to book value (PBV) rasio dihitung dengan:

$$
\mathrm{PBV}=\frac{\text { Harga Pasar per saham }}{\text { Nilai buku per Saham }}
$$

\section{b. Variabel Independen}

Variabel independen dalam penelitian ini adalah:

1. Kebijakan Dividen (X1) 
Kebijakan dividen dalam penelitian ini diukur dengan dividend payout ratio (DPR), Menurut Brigham dan Houston (2006) Dividend Payout Ratio merupakan suatu proksi mengukur kebijakan perusahaan untuk membayarkan dividen terhadap nilai perusahaan. Dividend Payout Ratio dapat dihitung dengan sebagai berikut:

2. Kebijakan Hutang (X2)

$$
\mathrm{DPR}=\frac{\text { Dividen } \text { Per Share }}{\text { Earning Per Share }}
$$

Hutang merupakan kewajiban perusahaan kepada pihak lain untuk membayar sejumlah uang atau menyerahkan barang atau jasa pada tanggal tertentu. Dalam penelitian ini kebijakan hutang diukur dengan Debt to Equity Ratio (DER). Menurut Kasmir (2008) Debt to Equity Ratio (DER) di ukur melalui perbandingan antara total hutang dengan equitas perusahaan. Debt to Equity Ratio dapat dihitung sebagai berikut:

3. Profitabilitas (X3)

$$
D E R=\frac{\text { Total debt }}{\text { Equity }}
$$

Pengukuran profitabilitas ini mengacu dari Return On Equity (ROE) merupakan rasio yang digunakan untuk mengukur laba bersih setelah pajak dengan modal sendiri. Menurut Kasmir (2008) return on equity dapat dihitung sebagai berikut:

$$
\mathrm{ROE}=\frac{\text { Earning After } \text { Tax }}{\text { Total Equity }}
$$

\section{Teknik Analisis Data}

Metode analisis data yang digunakan dalam penelitian ini adalah analisis regresi linier berganda. Berdasarkan mekanisme hubungan antar variabel maka formulasi matematis dalam penelitian ini adalah sebagai berikut:

$$
\mathrm{Y}=\mathrm{a}+\mathrm{b} 1 \mathrm{X1}+\mathrm{b} 2 \mathrm{X2}+\mathrm{b3} \mathrm{X3}+\mathrm{e}
$$

Dimana :

$$
\begin{array}{ll}
\text { Y } & \text { : Variabel Dependen } \\
\text { a } & \text { : Konstanta } \\
\text { b1, b2, b3, } & \text { : Koefisien X1, X2, X3 } \\
\text { X1 } & \text { : Variabel independen pertama } \\
\text { X2 } & \text { : Variabel independen kedua } \\
\text { X3 } & \text { : Variabel independen ketiga } \\
\text { e } & \text { : Disturbance error (faktor pengganggu/residual) }
\end{array}
$$




\section{Pengujian Asumsi Klasik}

Untuk menentukan ketepatan model regresi perlu dilakukan pengujian atas beberapa asumsi klasik yang mendasari model regresi sebagai berikut:

1. Uji Normalitas, untuk mendeteksi residual berdistribusi normal atau tidak yaitu dengan menggunakan uji statistik non parametrik KolmogorovSmirnov.

Kriteria pengambilan keputusan yaitu:

a. Jika nilai signifikansi $>0,05$ maka data berdistribusi normal

b. Jika nilai signifikansi $<0,05$ maka data tidak berdistribusi normal.

2. Uji Multikolonieritas, Untuk mendeteksi ada tidaknya multikolinieritas dalam model regresi dapat dilihat dari tolerance value atau variance inflation factor (VIF). Sebagai syarat dasarnya dapat disimpulkan:

1. Jika nilai tolerance $>0,10$ dan nilai $\mathrm{VIF}<10$, maka dapat disimpulkan bahwa tidak ada multikolinieritas

2. Jika nilai tolerance $<0,10$ dan nilai $\mathrm{VIF}>10$, maka dapat disimpulkan bahwa ada terjadi multikolinieritas antar variabel independen dalam model regresi.

\section{Uji Heteroskedastisitas}

Untuk mengetahui ada atau tidaknya autokorelasi dalam suatu model regresi dilakukan pengujian dengan menggunakan Uji Durbin-Watson (DW test). Pengambilan keputusan ada tidaknya autokorelasi:

(a) Jika $0<\mathrm{d}<\mathrm{dl}$, maka tidak ada autokorelasi positif.

(b) Jika $\mathrm{dl} \leq \mathrm{d} \leq \mathrm{du}$, maka tidak ada autokorelasi positif.

(c) Jika 4 - dl $<\mathrm{d}<4$, maka tidak ada autokorelasi negatif.

(d) Jika $4-\mathrm{du} \leq \mathrm{d} \leq 4-\mathrm{dl}$, maka tidak ada autokorelasi negatif.

(e) Jika du $<\mathrm{d}<4-\mathrm{du}$, maka tidak ada autokorelasi positif maupun negatif.

\section{Statistik Deskriptif}

Menurut Ghozali (2005) statistik deskriptif adalah teknik dalam statistika yang bertujuan untuk memberikan gambaran atau deskripsi suatu data. Dalam penelitian ini statistik deskriptif yang digunakan adalah nilai rata-rata (mean), deviasi standar (standard deviation), nilai maksimum dan nilai minimum.

\section{Pengujian Hipotesis}

1. Uji t

Pengujian ini dilakukan untuk mengetahui apakah terdapat pengaruh signifikan dari kebijakan dividen, kebijakan utang dan 
profitabilitas terhadap nilai perusahaan secara parsial terhadap nilai perusahaan manufaktur di Bursa Efek Indonesia untuk periode 2009-2013.

\section{Hasil Penelitian dan Pembahasan}

\section{Hasil Penelitian}

a. Hasil Uji Asumsi Klasik

1. Hasil Uji Normalitas

Tabel. 1. Hasil Uji Normalitas

One-Sample Kolmogorov-Smirnov Test

\begin{tabular}{|ll|r|r|r|r|}
\hline & & \multicolumn{1}{|c|}{ PBV } & \multicolumn{1}{c|}{ DPR } & DER & \multicolumn{1}{c|}{ ROE } \\
\hline $\mathrm{N}$ & & 135 & 135 & 135 & 135 \\
Normal Parameters ${ }^{\mathrm{a}, \mathrm{b}}$ & Mean & 5.0002 & .4387 & .8651 & .3159 \\
& Std. Deviation & 8.32635 & .30355 & 1.04057 & .35675 \\
\multirow{2}{*}{ Most Extreme Differences } & Absolute & .307 & .138 & .224 & .288 \\
& Positive & .307 & .138 & .202 & .288 \\
& Negative & -.285 & -.082 & -.224 & -.215 \\
Kolmogorov-Smirnov Z & & 3.573 & 1.609 & 2.599 & 3.344 \\
Asymp. Sig. (2-tailed) & & .000 & .011 & .000 & .000 \\
\hline
\end{tabular}

a. Test distribution is Normal.

b. Calculated from data.

\section{Sumber: Pengolahan Data SPSS IBM 19}

Berdasarkan Tabel 1. dapat diketahui bahwa hasil pengujian normalitas menunjukkan bahwa semua variabel tidak berdistribusi normal, dimana nilai asymp.sig. (2-tailed) untuk variabel price to book value, dividend payout ratio, debt to equity ratio, dan return on equity bernilai < 0,05 yang berarti data tersebut tidak berdistribusi normal. Hasil pengujian normalitas yang kedua diperoleh tampak dalam Tabel 4.6 sebagai berikut:

Tabel 2. Hasil Uji Normalitas Setelah Outlier

One-Sample Kolmogorov-Smirnov Test

\begin{tabular}{|ll|r|r|r|r|}
\hline & & \multicolumn{1}{c|}{ PBV } & \multicolumn{1}{c|}{ DPR } & \multicolumn{1}{c|}{ DER } & \multicolumn{1}{c|}{ ROE } \\
\hline $\mathrm{N}$ & & 97 & 97 & 97 & 97 \\
Normal Parameters ${ }^{\mathrm{a}, \mathrm{b}}$ & Mean & 2.8676 & .3680 & .5243 & .2247 \\
& Std. Deviation & 1.76408 & .19768 & .32641 & .08798 \\
Most Extreme Differences & Absolute & .130 & .071 & .131 & .088 \\
& Positive & .130 & .071 & .131 & .088 \\
& Negative & -.088 & -.044 & -.086 & -.075 \\
Kolmogorov-Smirnov Z & & 1.279 & .701 & 1.293 & .867 \\
Asymp. Sig. (2-tailed) & & .076 & .710 & .070 & .440 \\
\hline
\end{tabular}

a. Test distribution is Normal.

b. Calculated from data. 


\section{Sumber: Pengolahan Data SPSS IBM 19}

Setelah dilakukan uji outlier, data sampel dalam penelitian ini menunjukkan bahwa semua variabel berdistribusi normal dimana nilai dari asymp.sig. (2-tailed) untuk semua variabel lebih besar dari 0,05 yaitu nilai asymp.Sig. (2-tailed) untuk price to book value sebesar 0,076, dividend payout ratio sebesar 0,710 , debt to equity ratio sebesar 0,070 , dan return on equity sebesar 0,440 .

2. Hasil Uji Multikoloniaeritas

Tabel 3. Hasil Uji Multikoloniaeritas

Coefficients $^{\mathrm{a}}$

\begin{tabular}{|c|c|c|c|c|c|c|c|c|}
\hline \multirow{2}{*}{\multicolumn{2}{|c|}{ Model }} & \multicolumn{2}{|c|}{$\begin{array}{c}\text { Unstandardized } \\
\text { Coefficients } \\
\end{array}$} & \multirow{2}{*}{$\begin{array}{c}\begin{array}{c}\text { Standardized } \\
\text { Coefficients }\end{array} \\
\text { Beta }\end{array}$} & \multirow[b]{2}{*}{$\mathrm{T}$} & \multirow[b]{2}{*}{ Sig. } & \multicolumn{2}{|c|}{ Collinearity Statistics } \\
\hline & & B & $\begin{array}{l}\text { Std. } \\
\text { Error }\end{array}$ & & & & Tolerance & VIF \\
\hline \multirow[t]{4}{*}{1} & (Constant) & .167 & .503 & & .332 & .741 & & \\
\hline & DPR & 2.693 & .756 & .302 & 3.561 & .001 & .938 & 1.066 \\
\hline & DER & -.633 & .447 & -.117 & -1.416 & .160 & .984 & 1.016 \\
\hline & ROE & 9.083 & 1.691 & .453 & 5.371 & .000 & .947 & 1.056 \\
\hline
\end{tabular}

a. Dependent Variable: PBV

Sumber: Pengolahan Data SPSS IBM 19

Nilai tolerance dari masing-masing variabel independen lebih dari 0,1 dan nilai VIF dari masing-masing variabel independen adalah kurang dari sepuluh sehingga dapat disimpulkan bahwa variabel independen dalam model regresi ini tidak terjadi multikolonieritas.

\section{Hasil Uji Heteroskedastisitas}

\section{Gambar 1. Hasil Uji Heteroskedastisitas}

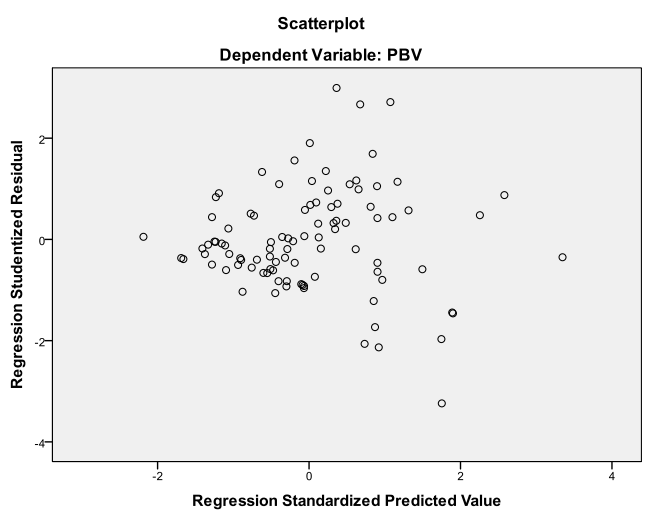


Berdasarkan Gambar 1 di atas, dapat diketahui bahwa tidak ada pola yang jelas dan titik-titik menyebar secara merata di atas dan di bawah angka nol. Hal ini dapat disimpulkan bahwa tidak terjadi heteroskedastisitas pada model regresi.

\section{Hasil Uji Autokorelasi}

\section{Tabel 4. Hasil Uji Autokorelasi}

Model Summary $^{\text {b }}$

\begin{tabular}{|l|r|r|r|r|r|}
\hline Model & $\mathrm{R}$ & R Square & $\begin{array}{c}\text { Adjusted R } \\
\text { Square }\end{array}$ & $\begin{array}{c}\text { Std. Error of the } \\
\text { Estimate }\end{array}$ & Durbin-Watson \\
\hline 1 & $.611^{\mathrm{a}}$ & .374 & .353 & 1.41856 & 1.956 \\
\hline
\end{tabular}

a. Predictors: (Constant), ROE, DER, DPR

b. Dependent Variable: PBV

Sumber: Pengolahan Data SPSS IBM 19

Dengan jumlah sampel penelitian $(n)=97$ dan jumlah variabel independen $=4(\mathrm{k}=3)$, maka diperoleh nilai $\mathrm{du}=1,7335$ dan $\mathrm{dl}=1,6063$. Berdasarkan hasil perhitungan menggunakan SPSS 19 pada tabel 4, nilai Durbin-Watson $(\mathrm{DW})=1$, 956. Dengan demikian nilai $\mathrm{du}<\mathrm{d}<4-\mathrm{du}$ $(1,7335<1,956<2,3937)$, sehingga dapat disimpulkan bahwa tidak terdapat autokorelasi positif atau negatif (bebas uji autokorelasi) pada regresi penelitian ini.

\section{b. Hasil Uji Stastistik Deskriptif}

\section{Tabel 5. Hasil Uji Stastistik Deskriptif}

\begin{tabular}{|l|r|r|r|r|r|}
\hline & \multicolumn{1}{|c|}{ Descriptive Statistics } \\
\hline PBV & \multicolumn{1}{|c|}{ Minimum } & Maximum & \multicolumn{1}{c|}{ Mean } & \multicolumn{1}{c|}{ Std. Deviation } \\
DPR & 97 & .48 & 7.83 & 2.8676 & 1.76408 \\
DER & 97 & .03 & .91 & .3680 & .19768 \\
ROE & 97 & .05 & 1.39 & .5243 & .32641 \\
Valid N (listwise) & 97 & .04 & .50 & .2247 & .08798 \\
\hline
\end{tabular}

Sumber: Pengolahan Data SPSS IBM 19

Berdasarkan tabel 5 menunjukkan bahwa dari jumlah data sebanyak 97 data, Price to book value (PBV) memiliki rata-rata sebesar 2,8676 dan nilai deviasi standar sebesar 1,76408 . Nilai terendah sebesar 0,48 dan nilai tertinggi 7,83 . 
Dividend payout ratio memiliki nilai rata-rata sebesar 0,3680 dan nilai deviasi standar sebesar 0,19768 . Nilai terendah sebesar 0,03 dan nilai tertinggi sebesar 0,91 .

Debt to equity ratio memiliki nilai rata-rata sebesar 0,5243 dan nilai deviasi standar sebesar 0,32641. Nilai terendah sebesar 0,39 dan nilai tertinggi sebesar 1,39.

Return on equity ratio memiliki nilai rata-rata sebesar 0,2247 dan nilai deviasi standar sebesar 0,08798. Nilai terendah sebesar 0,04 dan nilai tertinggi 0,50 .

\section{Hasil Penelitian}

\section{a. Regresi Linier Berganda}

\begin{tabular}{|c|c|c|c|c|c|}
\hline \multicolumn{6}{|c|}{ Coefficients ${ }^{\mathrm{a}}$} \\
\hline \multirow[b]{2}{*}{ Model } & \multicolumn{2}{|c|}{$\begin{array}{l}\text { Unstandardized } \\
\text { Coefficients }\end{array}$} & \multirow{2}{*}{$\begin{array}{c}\begin{array}{c}\text { Standardized } \\
\text { Coefficients }\end{array} \\
\text { Beta }\end{array}$} & \multirow[b]{2}{*}{$\mathrm{t}$} & \multirow[b]{2}{*}{ Sig. } \\
\hline & $\mathrm{B}$ & Std. Error & & & \\
\hline $1 \quad$ (Constant) & .167 & .503 & & .332 & .741 \\
\hline DPR & 2.693 & .756 & .302 & 3.561 & .001 \\
\hline DER & -.633 & .447 & -.117 & -1.416 & .160 \\
\hline ROE & 9.083 & 1.691 & .453 & 5.371 & .000 \\
\hline
\end{tabular}

a. Dependent Variable: PBV

Sumber: Pengolahan Data SPSS IBM 19

Dari tabel di atas dapat diperoleh persamaan regresi linear berganda sebagai berikut: $\mathrm{Y}=0,167+2,693 \mathrm{X} 1-0,633 \mathrm{X} 2+9,083 \mathrm{X} 3+\mathrm{e}$

\section{b. Hasil Uji Secara Parsial (Uji t)}

Tabel 6. Hasil Uji Secara Parsial

\begin{tabular}{|c|c|c|c|c|c|}
\hline \multicolumn{6}{|c|}{ Coefficients $^{\mathbf{a}}$} \\
\hline \multirow[b]{2}{*}{ Model } & \multicolumn{2}{|c|}{$\begin{array}{c}\text { Unstandardized } \\
\text { Coefficients }\end{array}$} & \multirow{2}{*}{$\begin{array}{c}\begin{array}{c}\text { Standardized } \\
\text { Coefficients }\end{array} \\
\text { Beta }\end{array}$} & \multirow[b]{2}{*}{$\mathrm{T}$} & \multirow[b]{2}{*}{ Sig. } \\
\hline & B & Std. Error & & & \\
\hline 1 (Constant) & .167 & .503 & & .332 & .741 \\
\hline DPR & 2.693 & .756 & .302 & 3.561 & .001 \\
\hline DER & -.633 & .447 & -.117 & -1.416 & .160 \\
\hline ROE & 9.083 & 1.691 & .453 & 5.371 & .000 \\
\hline
\end{tabular}

a. Dependent Variable: PBV

Sumber: Pengolahan Data SPSS IBM 19 
Kebijakan dividen diperoleh koefisien regresi dengan arah positif sebesar 2,693. Kebijakan dividen memiliki nilai sig. Sebesar 0,001 dimana 0,001 < 0,05 dan nilai $\mathrm{t}_{\text {hitung }} 3,561>\mathrm{t}_{\text {tabel }} 1,986$, sehingga Ho ditolak dan $\mathrm{Ha}$ diterima.

Debt to equity ratio diperoleh koefisien regresi dengan arah negatif sebesar 0,633 . Debt to equity ratio memiliki nilai sig. 0,160 dimana 0,160 $>0,05$ dan nilai $t_{\text {hitung }}-1,416<t_{\text {tabel }} 1,986$, Dengan demikian, dapat diambil kesimpulan bahwa variabel debt to equity ratio mempunyai pengaruh negatif dan tidak signifikan terhadap nilai perusahaan.

Return on equity diperoleh koefisien regresi dengan arah positif sebesar 9,083. Return on equity memiliki nilai sig. Sebesar 0,000 dimana $0,000<0,05$ dan nilai $t_{\text {hitung }} 5,371>\mathrm{t}_{\text {tabel }} 1,986$, Dengan demikian, dapat diambil kesimpulan bahwa variabel return on equity mempunyai pengaruh positif dan signifikan terhadap nilai perusahaan.

\section{b. Hasil Uji Secara Simultan (Uji F)}

\section{Tabel 7. Hasil Uji Secara Simultan (Uji F)}

\begin{tabular}{|ll|r|r|r|r|r|}
\hline Model & & Sum of Squares & \multicolumn{1}{|c|}{ Df } & Mean Square & F & \multicolumn{1}{c|}{ Sig. } \\
\hline 1 & Regression & 111.608 & 3 & 37.203 & 18.488 & $.000^{\mathrm{a}}$ \\
& Residual & 187.144 & 93 & 2.012 & & \\
& Total & 298.751 & 96 & & & \\
\hline
\end{tabular}

a. Predictors: (Constant), ROE, DER, DPR

b. Dependent Variable: PBV

Sumber: Pengolahan Data SPSS IBM 19

Nilai sig dari model penelitian ini adalah sebesar 0,000 dimana nilai $0,000<0,05$ dan $F_{\text {hitung }} 18,488>F_{\text {tabel }} 2,47$ maka Ha diterima dan Ho ditolak, artinya kebijakan dividen, kebijakan hutang dan profitabilitas secara bersama-sama mempunyai pengaruh signifikan terhadap nilai perusahaan.

\section{PEMBAHASAN}

\section{Pengaruh Kebijakan Dividen terhadap Nilai Perusahaan pada Perusahaan Manufaktur di Bursa Efek Indonesia}

Tanda positif pada koefisien regresi variabel menunjukkan bahwa adanya hubungan positif dengan nilai perusahaan. Semakin naik DPR yang ditetapkan oleh perusahaan maka semakin tinggi pula jumlah laba yang akan dibayarkan sebagai dividen pada pemegang saham. Hal ini ditangkap 
oleh investor sebagai sinyal positif dari perusahaan sehingga akan meningkatkan kepercayaan investor serta akan mempermudah manajemen perusahaan untuk menarik modal dalam bentuk saham. Apabila terdapat kenaikan permintaan saham suatu perusahaan, maka secara tidak langsung akan menaikkan harga saham, selanjutnya nilai perusahaan juga akan meningkat.

Hasil penelitian ini didukung oleh penelitian Bambang (2009) yang menyatakan bahwa kebijakan dividen berpengaruh positif terhadap nilai perusahaan. Namun hasil penelitian ini tidak sesuai dengan penelitian yang dilakukan oleh Putri Prihatin Ningsih dan Lin Indarti (2010) yang menyatakan bahwa kebijakan dividen tidak berpengaruh positif dan signifikan terhadap nilai perusahaan.

\section{Pengaruh Kebijakan Hutang terhadap Nilai Perusahaan pada Perusahaan Manufaktur di Bursa Efek Indonesia}

Kebijakan hutang diperoleh koefisien regresi dengan arah negatif sebesar 0,633. Debt to equity ratio memiliki nilai sig. 0,160 dimana 0,160 $>0,05$ dan nilai $t_{\text {hitung }}-1,416<\mathrm{t}_{\text {tabel }} 1,986$, sehingga Ho diterima dan Ha ditolak. Dari penjelasan tersebut dapat disimpulkan bahwa variabel kebijakan hutang mempunyai pengaruh negatif dan tidak signifikan terhadap nilai perusahaan sehingga hipotesisnya ditolak.

Tanda negatif pada penelitian ini menunjukkan bahwa kebijakan hutang berbanding terbalik dengan nilai perusahaan. Apabila DER mengalami peningkatan maka nilai perusahaan akan mengalami penurunan, dan sebaliknya.

Tidak signifikannya kebijakan hutang dengan nilai perusahaan menjelaskan bahwa dimana tinggi rendahnya hutang yang dimiliki perusahaan tidak mempengaruhi keputusan pemegang saham dalam meningkatkan nilai perusahaan. Maka sebaiknya perusahaan tidak sepenuhnya dibiayai dengan hutang, agar perusahaan tidak menimbulkan risiko kebangkrutan semakin tinggi.

Hasil penelitian ini sejalan dengan teori yang dikemukakan oleh Modigliani dan Miller (MM) dalam Atmaja (2003) menyatakan bahwa rasio hutang tidak relevan dan tidak ada hubungannya dengan struktur modal yang optimal. Nilai perusahaan bergantung pada arus kas yang akan dihasilkan dan bukan pada rasio hutang dan ekuitas. Inti dari teori ini adalah tidak ada rasio hutang yang optimal dan rasio hutang tidak menjelaskan nilai perusahaan. Menurut Brigham dan Houston (2006) kebijakan hutang memiliki keunggulan dan kelemahan. Penggunaan modal 
hutang akan menguntungkan apabila iklim bisnis baik sehingga manfaat dari penggunaan hutang akan lebih besar dari biaya bunga, namun demikian dalam iklim bisnis yang tidak menentu manfaat dari penggunaan hutang bisa lebih kecil dari biaya yang ditimbulkan. Hasil ini tidak sesuai dengan penelitian yang dilakukan oleh Umi Mardiyati, Gatot Nazir dan Ria Putri (2012) yang menyatakan bahwa kebijakan hutang berpengaruh positif terhadap nilai perusahaan.

\section{Pengaruh Profitabilitas terhadap Nilai Perusahaan pada Perusahaan Manufaktur di Bursa Efek Indonesia}

Hasil penelitian ini menunjukkan bahwa profitabilitas mempunyai pengaruh positif dan signifikan terhadap nilai perusahaan. Hal ini ditunjukkan diperoleh koefisien regresi dengan arah positif sebesar 9,083. Profitabilitas memiliki nilai sig. Sebesar 0,000 dimana $0,000<0,05$ dan nilai $\mathrm{t}_{\text {hitung }} 5,371>\mathrm{t}_{\text {tabel }} 1,986$, sehingga Ho ditolak dan Ha diterima. Dengan demikian, dapat diambil kesimpulan bahwa variabel profitabilitas mempunyai pengaruh positif dan signifikan terhadap nilai perusahaan. Hal ini menunjukkan semakin tinggi nilai laba yang didapat maka akan semakin tinggi tingkat pengembalian yang diperoleh perusahaan, dengan demikian return saham juga akan semakin besar. Hal ini akan memberikan indikasi prospek perusahaan yang baik sehingga dapat memicu investor untuk ikut meningkatkan permintaan saham. Permintaan saham yang meningkat akan menyebabkan nilai perusahaan yang meningkat.

Hasil penelitian ini sesuai dengan hasil penelitian yang dilakukan oleh Umi Mardiyati, Gatot Nazir Ahmad dan Ria Putri (2012) yang menyatakan bahwa profitabilitas berpengaruh positif dan signifikan terhadap nilai perusahaan. Namun hasil penelitian ini tidak sesuai dengan hasil penelitian yang dilakukan oleh Dedi Januardy (2013) yang menyatakan bahwa profitabilitas berpengaruh negatif terhadap nilai perusahaan.

\section{KESIMPULAN DAN SARAN KESIMPULAN}

Berdasarkan analisis dan pembahasan yang dilakukan terhadap 27 sampel perusahaan manufaktur yang terdaftar di Bursa Efek Indonesia dengan tahun penelitian 2009 sampai dengan 2013, maka diperoleh kesimpulan sebagai berikut:

1. Berdasarkan hasil pengujian hipotesis untuk variabel kebijakan dividen diperoleh nilai koefisien regresi dengan arah positif sebesar 
2,693 dan nilai sig. sebesar 0,001 dimana $0,001<0,05$ dan nilai $t_{\text {hitung }}$ $3,561>t_{\text {tabel }} 1,986$. Hal tersebut menunjukkan bahwa secara parsial variabel kebijakan dividen mempunyai pengaruh positif dan signifikan terhadap variabel nilai perusahaan.

2. Berdasarkan hasil pengujian hipotesis untuk variabel kebijakan hutang diperoleh koefisien regresi dengan arah negatif sebesar 0,633 dan nilai sig. Sebesar 0,160 dimana $0,160>0,05$ dan nilai $t_{\text {hitung }}-1,416<$ $\mathrm{t}_{\text {tabel }}$ 1,986, sehingga Ho diterima dan Ha ditolak. Hal tersebut menunjukkan bahwa secara parsial variabel kebijakan hutang mempunyai pengaruh negatif dan tidak signifikan terhadap nilai perusahaan.

3. Berdasarkan hasil pengujian hipotesis untuk variabel profitabilitas diperoleh koefisien regresi dengan arah positif sebesar 9,083 dan nilai sig. sebesar 0,000 dimana $0,000<0,05$ dan nilai $t_{\text {hitung }} 5,371>t_{\text {tabel }}$ 1,986. Hal tersebut menunjukkan bahwa variabel profitabilitas mempunyai pengaruh positif dan signifikan terhadap nilai perusahaan.

4. Berdasarkan uji $\mathrm{F}$ diperoleh nilai sig sebesar 0,000 dimana nilai 0,000 $<0,05$ dan $\mathrm{F}_{\text {hitung }} 18,488>\mathrm{F}_{\text {tabel }} 2,47$. Hal tersebut menunjukkan variabel kebijakan dividen, kebijakan hutang dan profitabilitas secara simultan mempunyai pengaruh signifikan terhadap nilai perusahaan. Nilai koefisien determinasi (Adjusted R Square) sebesar 0,353, artinya nilai perusahaan dapat dijelaskan oleh kebijakan dividen, kebijakan hutang dan profitabilitas sebesar $35,3 \%$ sedangkan sisanya dijelaskan oleh variabel lain.

\section{SARAN}

Untuk penelitian-penelitian selanjutnya hendaknya menambah variabelvariabel lainnya yang dapat mempengaruhi nilai perusahaan, karena masih banyak variabel-variabel yang memiliki pengaruh terhadap nilai perusahaan. Selain itu, untuk periode pengamatan hendaknya melakukan pengamatan dengan periode yang lebih lama dan memperluas cakupan sampel agar lebih mewakili perusahaan go public yang terdapat di Indonesia. 


\section{DAFTAR PUSTAKA}

Atmaja, Lukas Setia. 2003. Manajemen Keuangan, Edisi revisi. Yogyakarta: Andi.

Bambang. 2009. Pengaruh Kebijakan Hutang, Kebijakan Investasi dan Kebijakan Dividen Terhadap Nilai Perusahaan Manufaktur Terdaftar Di BEI Tahun 2003-2007. Jurnal Fakultas Ekonomi Universitas Sebelas Maret Surakarta.

Brigham, Eugene F. dan Joel F. Houston. 2010. Dasar-Dasar Manajemen Keuangan . Jakarta: Salemba Empat.

Dedi Januardy. 2013. Analisis Pengaruh Arus Kas, Profitabilitas dan Tingkat Suku Bunga Terhadap Nilai Perusahaan Pada Perusahaan Perbankan Yang Terdaftar Di BEI. Skipsi. Medan: Sekolah Tinggi Ilmu Ekonomi MIKROSKIL.

Ghozali, Imam. 2005. Aplikasi Analisis Multivariate dengan Program SPSS. Semarang: Badan Penerbit Universitas Diponegoro.

Husnan, suad. 2006. Dasar-Dasar Manajemen Keuangan Edisi Kelima. Yogyakarta: UPP STIM YKPN.

Jusriani. 2013. Analisis Pengaruh Profitabilitas, Kebijakan Dividen, Kebijakan Utang dan Kepemilikan Manajerial Terhadap Nilai Perusahaan. Jurnal Universitas Diponegoro, Semarang.

Kasmir. 2008. Analisis Laporan Keuangan. Jakarta: PT. Raja Grafindo Persada.

Kieso, dkk. 2008. Akuntansi Intermediate. Jakarta: Erlangga.

Karjono, Albertus dan Rony F. Matondang. 2010. Beberapa Faktor yang Mempengaruhi Dividen Payout Ratio pada Perusahaan Manufakturyang Terdaftar di BEI. Jurnal Esensi. Vol. 13, No. 1.

Munawir. 2004. Analisa Keuangan Laporan Keuangan. Yogyakarta: Liberty.

Novatiani. R. Ait dan Novi Oktaviani. 2013. Pengaruh Profitabilitas, Likuiditas, Leverage, dan Ukuran Perusahaan terhadap Kebijakan Dividen pada Perusahaan Manufaktur di Sektor Industri Barang Konsumsi yang Terdaftar di Bursa Efek Indonesia. Jurnal Fakultas Ekonomi Universitas Widyatama Bandung.

Sawir, Agnes. 2005. Analisis Kinerja Keuangan dan Perencanaan Keuangan Perusahaan. Jakarta: PT. Gramedia Pusaka Utama. 
Sartono, Agus. Manajemen Keuangan Teori dan Aplikasi. Yogyakarta: BPFE

Syahyunan. 2013. Manajemen Keuangan 2. Medan: USU Pres.

Tampubolon, Bantu. 2004. Akuntansi Keuangan. Medan: Universitas HKBP Nommensen.

www.idx.co.id 